\title{
Coated Granule Dosage Form
}

National Cancer Institute

\section{Source}

National Cancer Institute. Coated Granule Dosage Form. NCI Thesaurus. Code C148551.

A granule whose outer shell is covered with a substance. 